\title{
THE PHYSICAL AND ORGANOLEPTIC CHARACTERISTICS OF GROUND RABBIT DENDENG FERMENTED WITH Lactobacillus plantarum
}

\author{
Anik Fadlilah ${ }^{1)}$, Djalal Rosyidi ${ }^{2),},{ }^{*}$ Agus Susilo ${ }^{2)}$ \\ 1) Postgraduate Student, Faculty of Animal Science, Universitas Brawijaya, Jl. Veteran, Ketawanggede, Kec. \\ Lowokwaru, Kota Malang, Jawa Timur Indonesia 65145 \\ ${ }^{2)}$ Lecturer of Animal Product Technology Department, Faculty of Animal Science, Universitas Brawijaya, \\ Jl. Veteran, Ketawanggede, Kec. Lowokwaru, Kota Malang, Jawa Timur Indonesia 65145 \\ Email: djalal_tht@ub.ac.id
}

Submitted 18 May 2020; Accepted 12 June 2020

\begin{abstract}
The purpose of this study was to determine the appropriate concentration of Lactobacillus plantarum and fermentation time used in fermented rabbit meat production as the main ingredient for producing ground dendeng. This study used a $4 \times 3$ factorial randomized block design with three replications, which consisted of different L. plantarum concentrations ( $0 \%$, $6 \%, 8 \%$, and $10 \% \mathrm{v} / \mathrm{w})$ and fermentation times (12 h, $18 \mathrm{~h}$, and $24 \mathrm{~h}$ ). Data were analyzed using two-way analysis of variance and continued with Duncan's multiple range tests. The concentration of $L$. plantarum and fermentation time had a highly significant effect $(\mathrm{P}<0.01)$ on the acidity. The $L$. plantarum concentration had a significant effect $(\mathrm{P}<0.05)$ while fermentation time had a highly significant effect $(\mathrm{P}<0.01)$ on $\mathrm{pH}$. The concentration of $L$. plantarum and fermentation time had no effect on $\mathrm{A}_{\mathrm{w}}$, color, and texture. The concentration of L. plantarum had no effect on flavor, taste, and overall acceptance of dendeng. The fermentation time had a highly significant effect $(\mathrm{P}<0.01)$ on the flavor, and gave a significant effect $(\mathrm{P}<0.05)$ on the taste and overall acceptance of dendeng. In conclusion, the concentration of L. plantarum suitable for ground dendeng of fermented rabbit meat was $6 \%$ with $18 \mathrm{~h}$ fermentation time to produce the best physical and organoleptic quality and to obtain consumer acceptance.
\end{abstract}

Keywords: Acidity; dendeng; fermentation; intermediate moisture meat product; rabbit meat 


\section{INTRODUCTION}

Meat protein consumption per capita based on the data of Indonesia Directorate General of Livestock and Animal Health (2019) has increased by $11.4 \%$ from 2016 to 2018. Meat protein consumption are from $6.62 \%$ beef, $3.68 \%$ pork, $78.62 \%$ broiler, $10.29 \%$ native chicken, and $0.74 \%$ other meat. One of the other meat sources available in Indonesia is rabbit meat, which contains $19.99 \%$ protein, $2.31 \%$ fat, $75,84 \%$ moisture, $0.43 \%$ carbohydrate and $110.47 \mathrm{Kcal} / 100 \mathrm{~g}$ gross energy (Fadlilah et al., 2020).

The consumption of rabbit meat in Indonesia is still low as most Indonesian assumed that the rabbit is not for consumption rather than as pet. Processing can be applied to improve the consumption and acceptance of rabbit meat. Rabbit meat can be processed into dendeng that is a familiar form of processed meat in Indonesia and have long shelf life (Yanis et al., 2013). Uncontrolled fermentation that occurs in the traditional making process of dendeng results in inconsistent quality of the final product.

In order to produce dendeng with consistent quality, the use of lactic acid bacteria as starter and controlled fermentation time are required. Lactobacillus plantarum is most widely used in the meat fermentation process as a starter, because of its ability to perform fermentation at high temperature around $30-40^{\circ} \mathrm{C}$ (Pelczar and Chan, 2007) compared to other fermentation bacteria. In addition, $L$. plantarum is homofermentative that does not produce gas (Buckle et al., 2009). L. plantarum will produce lactic acid during fermentation that will affect the physical and organoleptic quality of meat.

The addition of $L$. plantarum to fermented goat meat product resulted in a significantly different result on $\mathrm{pH}$, acidity, and total plate count. Application of $30 \mathrm{~mL}$ L. plantarum resulted in better characteristics in terms of $\mathrm{pH}$, acidity, and a high number of total plate count of fermented goat meat dendeng (Umam et al., 2019). Isolated $L$. plantarum 1B1 from beef generally possesses good fermentation ability and still viable at the end of the process.

The results of the metabolism of $L$. plantarum 1B1 during fermentation can maintain conditions free of pathogenic bacteria such as Salmonella spp. and E. coli both on sliced and ground beef dendeng (Wardoyo, 2008). L. plantarum can ferment dark firm dry (DFD) beef and affect its physical properties, especially for the $\mathrm{pH}$ value, tenderness and color of meat (Arief $e t$ al., 2006).

There is lack of information regarding the use of $L$. plantarum to ferment rabbit meat that is used for producing ground dendeng, so it is necessary to observe the effect of different $L$. plantarum concentration and fermentation times on the physical and organoleptic characteristic of ground dendeng made from fermented rabbit meat.
*Corresponding author:

Djalal Rosyidi

Email: djalal_tht@ub.ac.id

Animal Product Technology Department, Faculty of Animal Science, Universitas Brawijaya, Jl. Veteran, Ketawanggede, Kec. Lowokwaru, Kota Malang, Jawa Timur Indonesia 65145
How to cite:

Fadlilah, A., Rosyidi, D., \& Susilo, A. (2020). The Physical and Organoleptic Characteristics of Ground Rabbit Dendeng Fermented with Lactobacillus plantarum. Jurnal Ilmu dan Teknologi Hasil Ternak, 15 (2), 108-118 


\section{MATERIALS AND METHODS}

\section{Materials}

The ground dendeng was made from rabbit meat, $L$. plantarum, and the seasonings consisted of palm sugar, salt, garlic, galangal, coriander powder, caraway, and large red chili. Fresh rabbit meat was bought from Adi Jaya Breeder (Batu City, Indonesia), L. plantarum liquid was bought from CV. Wiyasa Mandiri (Malang City, Indonesia), and the seasonings were bought from local market. The materials used for analysis were distilled water, buffer $\mathrm{pH} 4$ and 7, phenolphthalein, $\mathrm{NaOH}$, and ethanol $70 \%$.

The production tools of ground dendeng of fermented rabbit meat were scales, knives, gloves, cutting boards, blenders, airtight jars, masking tape, blue tips, micropipettes, Bunsen burner, mortar, spoons, plastics, rolling pin, incubator and oven. The analysis tools were scales, mortar, scissors, beaker glass, $\mathrm{pH}$ meter, burette, pipette, Erlenmeyer, $a_{w}$ meter, texture analyzer.

\section{Experimental design}

This study used a $4 \times 3$ factorial randomized block design with three replications. The first factor was different $L$. plantarum concentrations $(0 \%, 6 \%, 8 \%$, and $10 \% \mathrm{v} / \mathrm{w})$ and the second factor was fermentation times (12 h, $18 \mathrm{~h}$, and $24 \mathrm{~h}$ ).

\section{Production of fermented ground rabbit dendeng (FGRD)}

The production of was according to the procedure of Danangjaya (2014). The all meat from the carcass was deboned. The visible fat and connective tissue were removed from the meat. The meat was weighed using scales (AB204-S, Mettler Toledo, Switzerland), ground using chopper
(HR-2939N, Philips, Indonesia) and put into air-tight jars. The liquid starter was weighed according to the treatment, dissolved in water, and put into the ground meat. The ground meat was fermented according to the treatment. Ground seasonings $(30 \%$ palm sugar, $5 \%$ salt, $2 \%$ coriander, $2 \%$ garlic, $2 \%$ large red chili, $1 \%$ galangal and $1 \%$ caraway seed) were added and mixed with the fermented ground meat manually. The ground dendeng batters were put into plastic bags and flattened using rolling pin until the thickness of $3 \mathrm{~mm}$ was obtained. Raw ground dendeng were put into the oven and cooked at $70^{\circ} \mathrm{C}$ for $120 \mathrm{~min}$. Sample was ground prior to analysis.

\section{Acidity measurement}

The acidity measurement was a measurement of the total titrated acid that assumed to be total lactic acid. The measurement procedure was based on the procedure of AOAC (2005). The FGRD $(2 \mathrm{~g})$ was added with $20 \mathrm{~mL}$ distilled water. The slurry was then added with three drops of $1 \%$ phenolphthalein. Titration was carried out using $0.1 \mathrm{~N} \mathrm{NaOH}$ solution until a pink color appears, then calculated using following formula:

Total titrable acidiy $(\%)=\frac{m L 0.1 \mathrm{~N} \mathrm{NaOH} \times 0.009}{\text { sample }(\mathrm{g})} \times 10$

\section{pH measurement}

Measurement of $\mathrm{pH}$ was performed using a $\mathrm{pH}$ meter (ST 3100, OHAUS, OHAUS Coorperation, USA) and according to the procedure of AOAC (2005). The probe of $\mathrm{pH}$ meter was calibrated using buffer $\mathrm{pH} 4$ and 7 . The ground sample (2g) was added with $20 \mathrm{~mL}$ distilled water and homogenized manually then measuring for $30 \mathrm{~s}$. The $\mathrm{pH}$ of the slurry was the measured at $36-37^{\circ} \mathrm{C}$. The probe was rinsed using distilled water prior to next measurement. 


\section{$A_{w}$ measurement}

The measurement of $a_{w}$ was performed using $a_{w}$ meter according to Suharyanto (2009). The probe was calibrated using saturated $\mathrm{NaOH}$ solution. A total of $5 \mathrm{~g}$ of the ground sample was put into a sample and run for the measurement.

\section{Organoleptic Measurement}

Organoleptic test was carried out by 7 trained panelists at the Faculty of Animal Husbandry, Brawijaya Univeristy. The variables observed were color, texture, aroma, taste and overall acceptance of FGRD. Organoleptic test was carried out by presenting 12 dendeng samples in a clear plastic that was uniformly colored and randomly coded then the panelists were asked to give a score to the sample with a level of preference based on a scale of 1-5 (Santoso, 2000).

The numerical scale used ranges from scale 1 to scale 5 that a score of 5 was the best value in the scoring. The color parameters consist of brown, dark brown, brownish red, red, and distorted. The texture based on panelist made it easy for FGRD to break up when bitten with its characteristic tender, light tender, very tender, tough and very tough. The flavor characteristics were consisting of very good dendeng flavor, good dendeng flavor, not good dendeng flavor, flavorless and distorted. The taste characteristics were consisting of savory, slightly savory, not savory, too sour and distorted. The overall acceptance characteristic of FGRD was an assessment of the whole assessment of color, texture, flavor and taste with their characteristics highly accepted, accepted, rather accepted, not accepted and deviated.

\section{Statistical Analysis}

Data were analyzed using two-way analysis of variance. Duncan multiple range test was then performed at $\mathrm{P}<0.05$ to determine the mean differences.

\section{RESULTS AND DISSCUSION}

\section{Acidity}

The lactic acid produced through the fermentation affected the acidity of ground rabbit dendeng. The acidity of FGRD are shown in Table 1 . The acidity of FGRD was affected by $L$. plantarum concentration and the fermentation time. The concentration of L. plantarum and fermentation time had a high significant effect $(\mathrm{P}<0.01)$ on the acidity of FGRD. However, there was no interaction between the two factors on the acidity of FGRD.

Table 1. The acidity characteristic of ground rabbit dendeng fermented with different concentrations of Lactobacillus plantarum at different fermentation times

\section{Concentration /}

\begin{tabular}{lccccc}
$\begin{array}{l}\text { Fermentation } \\
\text { Time }\end{array}$ & $0 \%$ & $6 \%$ & $8 \%$ & $10 \%$ & Mean \\
\hline $12 \mathrm{~h}$ & 0.35 & 0.47 & 0.51 & 0.57 & $0.47 \pm 0.09^{\mathrm{a}}$ \\
$18 \mathrm{~h}$ & 0.47 & 0.48 & 0.53 & 0.56 & $0.51 \pm 0.07^{\mathrm{ab}}$ \\
$24 \mathrm{~h}$ & 0.53 & 0.48 & 0.57 & 0.59 & $0.54 \pm 0.06^{\mathrm{b}}$ \\
\hline Mean & $0.45 \pm 0.09^{\mathrm{a}}$ & $0.48 \pm 0.07^{\mathrm{a}}$ & $0.54 \pm 0.06^{\mathrm{b}}$ & $0.57 \pm 0.03^{\mathrm{b}}$ & \\
\hline
\end{tabular}

Description: Superscript in the same line and column showed the highly significant effect $(\mathrm{P}<0.01)$ 
The increasing of acidity due to $L$. plantarum was a lactic acid bacteria that produced lactic acid as the main result of the fermentation process, so the amount of lactic acid was directly proportional to the increase in concentration of $L$. plantarum bacteria and the length of fermentation time used. $L$. plantarum utilizes glycogen in meat to produce lactic acid. Glycogen in meat is converted to lactic acid through the process of glycolysis (Cocconcelli and Fontana, 2008). Some factors that influence lactic acid bacteria (LAB) activity in producing lactic acid are the number of starters used, the type of starter, and environmental conditions (Bourdichon et al., 2012). According to Khotimah and Kusnadi (2014), the presence of lactic acid bacteria in remodeling existing nutrients from meat to lactic acid could cause increasing in total acid value. Fermentation time of $18 \mathrm{~h}$ was the best time for the growth of L. plantarum bacteria. The logarithmic phase (exponential phase) was characterized by a significant increase in the bacterial population. Generally in the logarithmic and stationary phases, lactic acid bacteria produce primary metabolites such as lactic acid, acetic acid, and hydrogen peroxide (Djide and Sartini, 2008).

\section{pH}

The characteristic of dendeng could be assessed by knowing the value of the $\mathrm{pH}$ that related to the acid content accumulated during the fermentation process by lactic acid bacteria. $\mathrm{pH}$ was a measurement of hydrogen ions $\left(\mathrm{H}^{+}\right)$, this situation was inversely proportional to the value of acidity. The use of $L$. plantarum had a significant effect $(\mathrm{P}<0.05)$ on $\mathrm{pH}$, while fermentation time had a highly significant effect $(\mathrm{P}<0.01)$ on dendeng $\mathrm{pH}$. However, there was no interaction between the two factors on the $\mathrm{pH}$ of FGRD. The $\mathrm{pH}$ of dendeng was showed in Table 2.

Table 2. The $\mathrm{pH}$ characteristic of ground rabbit dendeng fermented with different concentrations of Lactobacillus plantarum at different fermentation times

\begin{tabular}{lccccc}
\hline $\begin{array}{l}\text { Concentration / } \\
\text { Fermentation } \\
\text { Time }\end{array}$ & $0 \%$ & $6 \%$ & $8 \%$ & $10 \%$ & Mean \\
\hline $12 \mathrm{~h}$ & 6.84 & 6.37 & 6.53 & 6.67 & $6.60 \pm 0.32^{\mathrm{b}}$ \\
$18 \mathrm{~h}$ & 6.36 & 6.20 & 6.00 & 5.68 & $6.06 \pm 0.52^{\mathrm{a}}$ \\
$24 \mathrm{~h}$ & 6.26 & 6.21 & 5.48 & 5.69 & $5.91 \pm 0.51^{\mathrm{a}}$ \\
\hline Mean & $6.49 \pm 0.28^{\mathrm{b}}$ & $6.26 \pm 0.27^{\mathrm{ab}}$ & $6.00 \pm 0.64^{\mathrm{a}}$ & $6.01 \pm 0.64^{\mathrm{a}}$ &
\end{tabular}

Description: Superscript in the same column showed the highly significant effect $(\mathrm{P}<0.01)$, Superscript in the same line showed the significant effect $(\mathrm{P}<0.05)$.

The concentration of L. plantarum at $6 \%$ had the acceptable $\mathrm{pH}$ for dendeng, which was $6.26 \pm 0.27$ and almost the same $\mathrm{pH}$ of dendeng without the use of $L$. plantarum. While the proper fermentation time to produce the acceptable $\mathrm{pH}$ of dendeng was at $12 \mathrm{~h}$ with a $\mathrm{pH}$ of $6.60 \pm 0.32$. Adam and Moss (2008) mentioned that the bacteria generally grow faster at $\mathrm{pH}$ 6-8. Fermented meat products have a $\mathrm{pH}$ between 4.5-5.0 and Aw 0.73 - 0.93. The more sugar added would affect the increasing of the $\mathrm{pH}$ of dendeng (Pursudarsono et al., 2015). Buckle et al. (2009) reported that the high sugar levels with low acid levels could add shelf life of 
food, because sugar contributes to the $\mathrm{OH}^{-}$ group which decreased the $\mathrm{pH}$. The increasing use of $L$. plantarum concentrations causes a decrease in dendeng $\mathrm{pH}$, as well as the longer fermentation. This situation was inversely proportional to the value of acidity. The acidity value is the value of the total acid titrated, while the $\mathrm{pH}$ is a measurement of hydrogen ions $\left(\mathrm{H}^{+}\right)$. The concentration of acid contained in the fermentation product affected the $\mathrm{pH}$ value. Increasing the concentration of lactic acid would be followed by an increasing in the concentration of hydrogen ions which were bound, so that the $\mathrm{pH}$ value decreased (Tamime, 2006). The decreasing of $\mathrm{pH}$ at the fermentation time was caused by an increasing in the number and metabolism of bacteria that produce lactic acid, so the $\mathrm{pH}$ value decreases.

Table 3. The activity water characteristic of ground rabbit dendeng fermented with different concentration of Lactobacillus plantarum at different fermentation times

\begin{tabular}{lccccc}
\hline $\begin{array}{l}\text { Concentration / } \\
\text { Fermentation } \\
\text { Time }\end{array}$ & $0 \%$ & $6 \%$ & $8 \%$ & $10 \%$ & Mean \\
\hline $12 \mathrm{~h}$ & 0.77 & 0.75 & 0.76 & 0.77 & $0.76 \pm 0.03$ \\
$18 \mathrm{~h}$ & 0.74 & 0.75 & 0.77 & 0.72 & $0.75 \pm 0.05$ \\
$24 \mathrm{~h}$ & 0.74 & 0.74 & 0.74 & 0.76 & $0.74 \pm 0.03$ \\
\hline Mean & $0.75 \pm 0.05$ & $0.75 \pm 0.02$ & $0.76 \pm 0.04$ & $0.75 \pm 0.04$ & \\
\hline
\end{tabular}

\section{Water activity}

Water activity $\left(a_{w}\right)$ describes the amount of free water in meat that could be used for biological activities of microorganisms. The $\mathrm{a}_{\mathrm{w}}$ of ground dendeng made from fermented rabbit meat was not affected by L. plantarum concentration and fermentation time. The $a_{w}$ values of ground dendeng of fermented rabbit meat are shown in Table 3.

The use of $L$. plantarum concentration up to $10 \%$ and fermentation time up to $24 \mathrm{~h}$ showed no effect on the $a_{w}$ of dendeng. same, and the $A_{w}$ mean of 12 hours to 24 hours had decreased of $A_{w}$. The drying of dendeng made the decrease of water in dendeng. Decreasing the water content would affect water activity, but it was related to the temperature used. Ikhsan et al., (2016) mentioned that the higher drying temperature used made the difference of water evaporation on the dendeng. The temperature of $60-70^{\circ} \mathrm{C}$ reduced the moisture content of dendeng from $34.88 \%$ to $10.05 \%$. In this research, there was an unstable temperature during drying, and the differences in humidity of the research location was vary so that the fermentation did not affect the $\mathrm{a}_{\mathrm{w}}$ of dendeng. The high environmental humidity caused the high value of dendeng $\mathrm{a}_{\mathrm{w}}$.

It happened when the dendeng was removed from the dryer, the process occurs to balance the in the air and dendeng by absorbing water droplets from the air. The relationship between $\mathrm{a}_{\mathrm{w}}$ and humidity was the equilibrium relationship between the free water content in the material and the moisture in the air. If the humidity was high, the material would absorb air water and if the free water content in the material was higher than in the air, the air would absorb the water material until a state of equilibrium was reached (Suharyanto, 2009). Higher temperature and longer heating time made a smaller value of water activity 
(Leviana and Paramita, 2017). The $\mathrm{a}_{\mathrm{w}}$ of FGRD ranged from 0.74 to 0.76 , which are within the Zone II of Labuza's model. Based on the Labuza's model, there were 3 zones for classifying the $\mathrm{a}_{\mathrm{w}}$; Zone I (0.1-0.2), Zone II (0.3-0.8), and Zone III (8-1.0). The zone II of Labuza's model was an active area for oxidation, non-enzymatic browning reaction, enzyme activity, hydrolysis, and mold growth.

Each microorganism requires different minimum $a_{w}$ for growth. Bacteria require minimum 0.91 , yeast 0.88 , and mold 0.80 . Therefore, based on the minimum $a_{w}$ requirements, heating at $60^{\circ} \mathrm{C}$ has been said to be safe to prevent the growth of bacteria, yeast, and mold (Fardiaz, 1992).

\section{Organoleptic characteristics}

The concentration of L. plantarum and fermentation time did not influence the color of FGRD. The score of color ranged from 4.30 to 4.51 . It showed that the dendeng had brown to dark brown appearance. The color of dendeng was affected by the addition of palm sugar in this study.

In addition, Jauhari et. al. (2005) reported that the darker color of dendeng was caused by grinding which could make the tissue fibers smoother and the fleshy fluid containing hemoglobin would come out to the surface, then the protein would react with glucose from sugar as a result brownish color through Maillard reaction. The color of dendeng was affected by the sugar content in the seasoning ingredients and the temperature used in the drying process.

The texture of FGRD was not affected by fermentation process. The concentration of L. plantarum and fermentation time did not affect the texture of dendeng. The score of color ranged from 3.62 to 3.92. This value when converted to texture parameters based on panelist scoring was very soft. It happened because there was meat grinding process before the fermentation, so that some meat tissue lost its water-binding ability. Further, the uneven heating caused the free water still remained in dendeng. Toldra (2010) said that the texture of a product depends on the amount of degraded myofibrillar protein, the degree of drying, and the degree of degradation of connective tissue in meat.

The phenomenon of shrinking meat samples was caused by shrinkage of muscle fibers due to protein denaturation by heat induction, thus pushing the flesh liquid (shrink) out of the sample and eventually evaporating. The most shrinking meat samples (dry) would have the least water content and the highest meat protein. Most drastic changes to meat during heating were shrinkage and hardening of the tissue, so that heating the meat could cause changes in the appearance, texture, and nutritional value of meat.

Protein denaturation affects the structure of the protein by weakening the bonds include hydrogen bonds (glycine), hydrophobic bonds (leucine, valine, phenylalanine, and tryptophan), ionic bonds, and intramolecular bonds such as disulfide groups in the system (Sumnu and Sahin, 2005). The concentration of $L$. plantarum did not give a significant effect on the flavor of dendeng, but the fermentation time gave a highly significant effect $(\mathrm{P}<0.01)$. The score of color ranged from 3.90 to 4.35 . This value means that the dendeng produced had a good dendeng flavor to good dendeng flavor. The $12 \mathrm{~h}$ and $18 \mathrm{~h}$ fermentation time resulted in the same score of flavor, while the $24 \mathrm{~h}$ fermentation time had the lowest score of flavor be-cause more time was used by L. plantarum to remodel production. The concentration of $L$. plantarum had no effect 
on the taste of dendeng, but different fermentation times gave a significant effect $(\mathrm{P}<0.05)$ on the taste of dendeng. The score of dendeng taste ranged from 4.00 to 4.33 . It means that the taste of dendeng was rather slightly savory or savory. The fermentation time of $18 \mathrm{~h}$ had a taste that was almost the same as the fermentation time of $12 \mathrm{~h}$. This indicates that the longer the fermentation was, the lower the taste of the dendeng was obtained. The existence of lactic acid, peptides, amino acids, and the free fatty acids generated through fermentation, proteolyisis and lipolysis, respectively, would affect the taste of the product produced (Toldra, 2010).

Table 4. The organoleptic characteristic of ground rabbit dendeng fermented with different concentration of Lactobacillus plantarum at different fermentation times

\begin{tabular}{|c|c|c|c|c|c|c|}
\hline Parameter & $\mathrm{FT}(\mathrm{hr})$ & $0 \%$ & $6 \%$ & $8 \%$ & $10 \%$ & Mean \\
\hline \multirow{4}{*}{ Colour } & 12 & 4.19 & 4.52 & 4.67 & 4.38 & $4.44 \pm 1.09$ \\
\hline & 18 & 4.33 & 4.38 & 4.62 & 4.43 & $4.44 \pm 0.81$ \\
\hline & 24 & 4.38 & 4.57 & 4.24 & 4.52 & $4.43 \pm 0.73$ \\
\hline & Mean & $4.30 \pm 0.69$ & $4.49 \pm 0.89$ & $4.51 \pm 0.86$ & $4.44 \pm 1.07$ & \\
\hline \multirow{4}{*}{ Texture } & 12 & 4.10 & 3.90 & 3.86 & 3.81 & $3.92 \pm 0.82$ \\
\hline & 18 & 3.86 & 3.62 & 3.76 & 3.86 & $3.77 \pm 1.01$ \\
\hline & 24 & 3.71 & 3.57 & 3.52 & 3.67 & $3.62 \pm 1.16$ \\
\hline & Mean & $3.89 \pm 1.05$ & $3.70 \pm 1.10$ & $3.71 \pm 1.03$ & $3.78 \pm 0.85$ & \\
\hline \multirow{4}{*}{ Flavor** } & 12 & 4.33 & 4.43 & 4.48 & 4.14 & $4.35 \pm 0.69^{b}$ \\
\hline & 18 & 4.71 & 4.19 & 4.10 & 4.38 & $4.35 \pm 0.99^{b}$ \\
\hline & 24 & 3.43 & 4.33 & 3.62 & 4.24 & $3.90 \pm 1.26^{\mathrm{a}}$ \\
\hline & Mean & $4.16 \pm 1.08$ & $4.32 \pm 0.85$ & $4.06 \pm 1.19$ & $4.25 \pm 0.93$ & \\
\hline \multirow{4}{*}{ Taste* } & 12 & 4.38 & 4.33 & 4.29 & 4.33 & $4.33 \pm 0.57^{b}$ \\
\hline & 18 & 4.48 & 3.90 & 3.86 & 4.10 & $4.08 \pm 1.17^{\mathrm{ab}}$ \\
\hline & 24 & 3.62 & 4.05 & 3.86 & 4.10 & $3.90 \pm 1.14^{\mathrm{a}}$ \\
\hline & Mean & $4.16 \pm 0.95$ & $4.09 \pm 0.93$ & $4.00 \pm 1.16$ & $4.17 \pm 0.99$ & \\
\hline \multirow{2}{*}{ Overall } & 12 & 4.00 & 3.76 & 3.86 & 3.76 & $3.85 \pm 0.74^{\mathrm{b}}$ \\
\hline & 18 & 4.19 & 3.71 & 3.76 & 4.00 & $3.92 \pm 1.04^{\mathrm{b}}$ \\
\hline \multirow{2}{*}{ Acceptance* } & 24 & 3.38 & 3.81 & 3.43 & 3.57 & $3.55 \pm 1.03^{\mathrm{a}}$ \\
\hline & Mean & $3.86 \pm 1.01$ & $3.76 \pm 0.95$ & $3.68 \pm 0.91$ & $3.78 \pm 0.91$ & \\
\hline
\end{tabular}

Note: ** had a highly significant effect $(\mathrm{P}<0.01), *$ had a significant effect $(\mathrm{P}<0.05)$

The dendeng taste produced was caused by sugar and spices mixed in the fermented rabbit meat mixture. The spices used in making beef dendeng give a pleasant flavor, taste, and could give a sense of consumer interest to taste it (Suryati et al., 2013). Adding spices to dendeng results in the availability of phenolic content in dendeng and improves its storage quality
(Suryati et al., 2013). The concentration of L. plantarum did not give any effect on the overall acceptance of dendeng, but fermentation time affected the overall acceptance of dendeng.

The overall acceptance score ranged from 3.55 to 3.92 , which showed that panelists rather accepted dendeng. The fermentation process resulted in the 
differences in texture and flavor of nonfermented commercial dendeng.

\section{CONCLUSION}

The fermentation time of $18 \mathrm{~h}$ and $L$. plantarum concentration of $6 \%$ were suggested because the dendeng $\mathrm{pH}$, acidity, and water activity were within the acceptable range and did not reduce its acceptance. Fermented ground rabbit dendeng obtained from this study had dark brown appearance, good dendeng flavor, savory, very soft and could be accepted by consumers.

\section{ACKNOWLEDGMENT}

The first author would like to thank Lembaga Pengelola Dana Pendidikan (LPDP) Scholarship from Ministry of Finance of the Republic of Indonesia for the research fund through postgraduate scholarship program.

\section{REFERENCES}

Adam, M. R., \& Moss, O. M. (2008). Food Microbiology (3rd ed.). The Royal Society of Chemistry.

AOAC (Association of Official Analytical Chemist). (2005). Official Method of Analysis of The Association of Official Analytical of Chemist (Arlington \& Virginia (eds.). Association of Official Analytical Chemist, Inc.

Arief, I. I., Suryati, T., \& Maheswari, R. R. A. (2006). Physical properties of dark firm dry beef (dfd) results of lactobacillus plantarum fermentation. Media Peternakan, 29(2), 76-82.

Bourdichon, F., Casaregola, S., Farrokh, C., Frisvad, J. C., Gerds, M. L., Hammes,
W. P., Harnett, J., Huys, G., Laulund, S., Ouwehand, A., Powell, I. B., Prajapati, J. B., Seto, Y., Ter Schure, E., Van Boven, A., Vankerckhoven, V., Zgoda, A., Tuijtelaars, S., \& Hansen, E. B. (2012). Food fermentations: Microorganisms with technological beneficial use. International Journal of Food Microbiology, 154(3), 87-97. https://doi.org/10.1016/j.ijfoodmicro. 2011.12.030

Buckle, K., Edwards, R. A., Fleet, G. H., \& Wootton, M. (2009). Food Science (H. Purnomo \& Adiono (eds.)). Penerbit Universitas Indonesia.

Cocconcelli, P. S., \& Fontana, C. (2008). Characteristic and Applications of Microbial Starters in Meat Fermentations and Meat Biotechnology (F. Toldra (ed.)). Springer.

Danangjaya, D. (2014). The Physic Characteristic of Ground and Sliced Dendeng of Rabbit Meat. Diponegoro University.

Directorate General of Livestock and Animal Health of Indonesia. (2017). Statistic Livestock and Animal Healt. Ministry of Agricultural of Indonesia Republic.

Fardiaz, S. (1992). Food and Nutrition Microbiology. Departemen Pendidikan dan Kebudayaan PAU Pangan dan Gizi.

Ikhsan, M., Muhsin, M., \& Patang, P. (2018). Pengaruh variasi suhu pengering terhadap mutu dendeng ikan lele dumbo (Clarias gariepinus). Jurnal 
Pendidikan Teknologi Pertanian, 2(2), 114-122. https://doi.org/10.26858/jp tp.v2i2.5166

Jauhari, J., Suryanto, E., \& Soeparno, S. (2012). Karakteristik organoleptik dendeng dari daging kambing bligon yang diberi pakan daun pepaya (Carica papaya) berbagai level. Buletin Peternakan, 29(3), 115-121. https://doi.org/10.21059/buletinpetern ak.v29i3.1177

Khotimah, K., \& Kusnadi, J. (2014). Antibacterial activity of Probiotic drink of date palm (Phoenix dactilyferes L) Juice using Lactobacillus plantarum dan Lactobacillus casei. Jurnal Pangan Dan Agroindustri, 2(3), 110-120.

Leviana, W., \& Paramita, V. (2017). Pengaruh suhu terhadap kadar air dan aktivitas air dalam bahan pada kunyit (Curcuma Longa) dengan alat pengering electrical oven. METANA, 13(2), 37-44. https://doi.org/10.14710 /metana.v13i2.18012

Nistor, E., Bampidis, V., P, N., Cal, C., Pentea, M., Tozer, J., \& Prundeanu, H. (2013). Nutrient content of rabbit meat as compared to chicken, beef and pork meat. Journal of Animal Production Advances, 3(4), 172-176. https://doi. org/10.5455/japa.20130411110313

Pursudarsono, F., Rosyidi, D., \& Widati, A. (2015). Effect of different salt and sugar concentration on dried lung qualities. Jurnal Ilmu Dan Teknologi Hasil Ternak, 10(1), 35-45. https://doi. org/10.21776/ub.jitek.2015.010.01.5
Santoso, S. (2000). Statistical Product and Service Solution (SPSS). Media Komputindo Kelompok Gramedia.

Suharyanto, S. (2009). Aktivitas air (Aw) dan warna dendeng daging giling terkait cara pencucian (leaching) dan jenis daging yang berbeda. Jurnal Sain Peternakan Indonesia , 4(2), 113120. https://doi.org/10.31186/jspi.id. 4.2.113-120

Sumnu, G., \& Sahin, S. (2005). Recent developments in microwave heating. Emerging Technologies for Food Processing, 53, 419-444. https:// doi.org/10.1016/B978-012676757-5/ 50018-9

Suryati, T., Astawan, M., Lioe, H. N., Wresdiyati, T., \& Usmiati, S. (2014). Nitrite residue and malonaldehyde reduction in dendeng influenced by spices, curing methods and precooking preparation. Meat Science, 96(3), 1403-1408. https://doi.org/10. 1016/j.meatsci.2013.11.023

Tamime, A. (2006). Fermented Milk. Blackwell Science.

Toldra, E. (2010). Meat Biotechnology. Springer.

Umam, A. K., Radiati, L. E., Susila, A., \& Hapsari, R. N. (2019). Chemical and microbiological quality of fermented goat meat dendeng with different levels of L. plantarum. IOP Conference Series: Earth and Environmental Science, 387, 1-5. https://doi.org/10.1088/1755-1315 /387/1/012012 
Wardoyo, D. Y. (2008). Microbiological Characteristics of Ground and Sliced Dendeng Fermented with Lactobacillus plantarum 1B1. Bogor Agricultural Institute.
Yanis, M., Aminah, S., Handayani, Y., \& Ramdhan, T. (2016). The characteristic of product from rabbit meat. Buletin Pertanian Perkotaan, 6(2), 11-25. 